\title{
Determinants of Bank Profitability: Empirical Evidence from Bangladesh
}

\author{
Mohammad Morshedur Rahman ${ }^{1,2}$, Md. Kowsar Hamid² \& Md. Abdul Mannan Khan ${ }^{3}$ \\ ${ }^{1}$ School of Management, Huazhong University of Science and Technology, Wuhan, Hubei, P. R. China \\ ${ }^{2}$ Department of Accounting and Information Systems, University of Chittagong, Chittagong, Bangladesh \\ 3 Department of Accounting and Information Systems, Bangabandhu Sheikh Mujibur Rahman Science and \\ Technology University, Gopalganj, Bangladesh \\ Correspondence: Mohammad Morshedur Rahman, School of Management, Huazhong University of Science and \\ Technology, Wuhan, Hubei, P. R. China. E-mail: rahmanmorshedur@yahoo.com
}

Received: May 25, 2015

doi:10.5539/ijbm.v10n8p135
Accepted: June 9, $2015 \quad$ Online Published: July 22, 2015

URL: http://dx.doi.org/10.5539/ijbm.v10n8p135

\begin{abstract}
This study attempts to investigate capital strength, credit risk, ownership structure, bank size, non-interest income, cost efficiency, off-balance sheet activities, liquidity as potential bank specific determinants as well as growth in gross domestic products, inflation as potential macroeconomic determinants of bank profitability by taking 25 commercial banks from Bangladesh for a period ranges from 2006 to 2013. Three different measures of profitability namely return on assets (ROA), net interest margin over total assets (NIM) and return on equity (ROE) are used in the study. The empirical findings suggest that capital strength (both regulatory capital and equity capital) and loan intensity has positive and significant impact on profitability. Results also show that cost efficiency and off-balance sheet activities have negative and significant impact on bank profitability. The impact of other variables is not uniform in respect of different measures of profitability. Non-interest income, credit risk and GGDP are found as important determinant for NIM. Size has a positive and significant impact on ROA. Finally inflation has a negative and significant impact on ROA and ROE.
\end{abstract}

Keywords: bank profitability, panel regression analysis, macroeconomic impact on bank profitability, banks in Bangladesh

\section{Introduction}

Microeconomic activities as well as macroeconomic activities of an economy largely depend on banking sector. Banking institutions are considered the lifeblood of any economy. The main role of a banking system is to assist the flow of funds from savers to borrowers. Banks are such types of business where deposits are considered as liabilities and issuing debt securities are considered as assets on the other part (Fama, 1980). If a financial system is efficient, then it should show profitability improvements, increasing volume of funds flowing from savers to borrowers, and better quality services for consumers (Sufian \& Habibullah, 2009). In Bangladesh, banking institutions are playing significant roles in the expansion of the financial system and the economy of the nation. It is notable that, the banking sector of developing countries is less stable than developed countries (Beck \& Rahman, 2006; Sufian \& Habibullah, 2009; Uddin \& Suzuki , 2011).

It is expected to maintain proper profit for any firm in order to survive. Recently, banking sector of Bangladesh is passing a critical path. Some commercial banks of Bangladesh are trying hard to keep their operations in proper ways. Banking sector of Bangladesh is increasing its appeal to customers, investors, and business people etc. Financial system of Bangladesh is rounding up through the orbit of banking industry. An efficient financial system improves banks' profitability by increasing the amount of funds available for investment, while enhancing the quality of services provided for the customers (Saona, 2011). As a guardian of all commercial banks, Bangladesh Bank (BB) has been taken a series of actions to improve the soundness, competitiveness, and efficiency of the banking system. Among them, changes relating to ownership, market concentration, regulatory measures and policies have taken place to improve banking performance.

Although BB has been taken some measures to stabilize the financial system and build confidence in the banking system, it is still relevant to know what factors affect banks profitability in order to influence policy making in 
the banking sector in Bangladesh. Thus, the study investigates the capital, risk, size, ownership structure, non-interest income to total assets, cost- to-income ratio, off balance sheet items to total assets, total liabilities to total debt, GDP growth rate, and inflation as potential determinants of banks' profitability in Bangladesh.

The remainder of the paper is arranged in the following manner. Section 2 shows the existing literature on the determinants of bank profitability. Section 3 discusses the data, variables and econometric model used in the study. Section 4 presents empirical findings. Section 5 reports the conclusion of the paper.

\section{Literature Review}

A lot of attention has given to discover the important determinants of bank profitability in whole world. Bank profitability can be expressed as a function of both internal and external factors. Internal factors can be referred as bank specific factors or micro factors and external factors can be referred as macroeconomic factors that affect the profitability of banks. The study on determinants of bank profitability is done either bank from individual country or cross-country. Chirwa (2003) examines the relationship between profitability and market structure in Malawi using time series data from commercial banks for the period between 1970 and 1994 . Time-series techniques of cointegration and error-correction mechanism are used in the study to see whether there is a long-run relationship between concentration and profitability of commercial banks. The empirical findings show that there is a long-run positive relationship between performance and concentration.

Doliente (2005) examines the determinants of NIM of banks in four Southeast Asian countries using the dealer model developed by Ho and Saunders (1981) and by running two-step regressions. Findings from the first regression show that the region's NIM are partially explained by capital, operating expenses, collateral and liquid assets, and loan quality. Results from Second step regression reveal that NIM is explained largely by the non-competitive structure of the region's banking systems. Furthermore, the results also reveal that in the aftermath of the banking and Asian currency crises, the profit grip experienced by the region's banks.

Park and Weber (2006) investigate the most important determinants of the Korean banking sector's profitability for the period ranges from 1992 to 2002 by testing the efficient structure hypothesis against the market structure hypothesis. The results show there is a significant association between bank efficiency and bank profitability which support the efficient structure hypothesis.

Micco, Panizza and Yañez (2007) reexamine the relationship between bank performance and ownership by using a new dataset. They try to give conclusions for both developed and developing countries separately. They find that for developing countries state-owned banks have a low level of profitability and a high level of costs comparing to private-owned banks. The results are just opposite for foreign-owned banks. On the other hand, they find that there is no significant relationship between performance and ownership in developed countries. It is also found that political consideration plays a significant role for the differential performance between private and public banks.

Kosmidou, Pasiouras, and Tsaklanganos (2007) seek to investigate the factors of profitability of banks from Greece operating abroad. They work on an unbalanced panel consisting 19 Greek bank subsidiaries working in 11 nations for a period of 1995-2001. The findings reveal that the operating experience and the level of profits of the parent bank have a positive impact on the profitability of subsidiaries in abroad, while the size of subsidiary bank has a negative impact on profitability. Liquidity, concentration or market share, domestic stock market developments, cost efficiency and loan loss provisions in the host nations are found as insignificant factors for subsidiary banks' profitability.

By using an empirical framework which integrates the traditional structure conduct-performance hypothesis, Athanasoglou, Brissimis and Delis (2008) see the impact of bank-specific, industry-specific and macroeconomic factors of bank performance. They use a GMM technique to a panel data taken from of Greek banks for the period 1985-2001. Their findings suggest that profitability in Greek banks is persisting to a moderate extent which explains that deviations from perfectly competitive market structures may is not large. There is a significant impact from all bank-specific variables except size on bank profitability. It is also revealed from the study that the business cycle has a positive impact on bank profitability.

Claeys and Vennet (2008) assess the factors of interest margins of banks from the Central and Eastern European countries (CEEC). Their results show that banking in the CEEC is on a worthy path and increased efficiency provides benefits to the customers, while capital adequacy wires systemic stability.

Sufian and Habibullah (2009) work on 37 commercial banks from Bangladesh to assess the performance for a period ranges from 1997 to 2004. They find that credit risk, loans intensity and cost have a significant and positive impact on performance of banks and non-interest income has a negative impact on bank performance. 
They don't find uniform impact from size to different measures of profitability. According to their findings, bank size is positively related with return on average assets and net interest margin. Opposite result is found for return on average equity. Regarding macroeconomic factors, they don't find any significant impact on profitability without for inflation that has a negative impact on banks performance during the period under study.

Working on Chinese banks, mainly on four state-owned commercial banks and 12 joint stock commercial banks, Sufian (2009) seeks to explore the main factors of profitability during the period from 2000 to 2007. The empirical findings show that credit risk, bank size, and capitalization have positive impact on the profitability. On the other have it is seen from the results that network embeddedness, overhead costs and liquidity have negative impacts on profitability. It is also seen from the findings that the impact of liquidity on profitability is not uniform across bank types. They find a positive impact from inflation and economic growth.

Naceur and Kandil (2009) examine the impact of capital regulations profitability and cost of intermediation. The interest of shareholders to manage the portfolios is increased due to a high level of capital adequacy which raises the profitability. The reduction in implicit cost, higher capital requirements and the raise in management efficiency have positive influence to the profitability of banks in the post-regulation period.

García-Herrero, Gavilá and Santabárbara (2009) analyze empirically the reasons for the low profitability in Chinese banks during 1997-2004. They find that banks with better capitalization and X-efficiencies have a tendency to become more profitable. Their results also show that bank profitability increases in a less concentrated banking system.

Heffernan and Fu (2010) seek to see the performance of Chinese banks between 1999 and 2006 and examine the determinants that affect the performance. The findings show that NIM and Economic Value Added do better than Return on Average Assets and Return on Average Equity. They also find that the type of bank is an influential factor of bank profitability while bank size is not an influential factor. They do not find any effect from the bank listing and the percentage of foreign ownership to profitability.

Albertazzi and Gambacorta (2009) assess the impact of corporate income tax on activity of banks taken from the main industrialized countries for the period of 1981-2003. The find that the taxation of profit of banks is equivalent to the taxation on loans and it has an impact on the composition of revenues in banking sector. There is ability for credit intermediaries to transfer a part of their tax burden and as a result differences in the level of taxation cannot explain the spreading observed in net profitability of banks.

Khediri and Ben-Khedhiri (2011) analyze the factors of net interest margins (NIM) in Tunisia by considering the heterogeneity of individual banks through the use of fixed-effect as well as random-effect models. According to the theoretical model suggesting positive association, they find that bank capital and operating costs are positively associated with NIM. It is also revealed from the study that NIM is negatively related to quality of management and positively related to implicit interest payments and opportunity costs of bank reserves.

By using the GMM estimator technique Dietrich and Wanzenried (2011) analyze the profitability of 372 commercial banks in Switzerland for a period from 1999 to 2009. To assess the impact of the recent financial crisis they consider the period in to two parts, the pre-crisis period ranges 1999 to 2006 and the crisis period ranges from 2007 to 2009 . Their results reveal that profitability determinants include bank-specific characteristics as well as industry-specific and macroeconomic factors, some of which have not been considered in previous studies. Capital, cost to income, credit quality, yearly growth of deposits, bank size, and funding costs are found as significant determinants of bank profitability.

Naceur and Omran (2011) investigate the impact of concentration, bank regulation, and institutional and financial development on margins and profitability of banks from Middle East and North Africa. Their findings show that credit risk and capitalization have a significant and positive influence on NIM of banks, profitability and cost efficiency. No significant influence from financial development indicators and macroeconomic on NIM are found except from inflation. Institutional and regulatory variables are found to have significant effect on performance of banks.

Westman (2011) investigate the impact of ownership structure on banks' profitability in Europe. Results show that there is a positive association between profitability and management ownership for non-traditional banks, whereas positive association between profitability and board ownership is found in traditional banks.

Bolt, Haan, Hoeberichts and Oordt (2012) take an attempt to contribute to the existing literature on the relation between economic activity and bank profitability. They find loan losses as the main driver of bank profitability. In times of high economic growth, they also find that long-term interest rates in previous years are important factors of bank profitability. Their findings are same for both individual as well as aggregate bank data. 
Kutan, Ozsoz and Rengifo (2012) examine the profitability of 36 dollarized banking systems. Findings reveal that dollarization discourages bank performance and as a result bank profitability will be low. It is also evidenced from the findings that the effect of institutions more than offsets the negative impact of dollarization on banks' profitability.

Sufian (2012) take an initiative to investigate the performance of 77 commercial banks taken from Pakistan, Sri Lanka and Bangladeshi during the period from 1997 to 2008. The empirical results show that credit risk, liquidity, capitalization and non-interest income have significant and positive impacts on the performance of banks, while there is a negative impact from cost on bank profitability. Regarding the macroeconomic determinants, the findings reveal that there is a positive and significant association between bank profitability and economic growth, while the association between profitability and inflation is not significant.

Tarusa, Yonas, and Mutwolc (2012) examine the factors of NIM of 44 commercial banks in Kenya by using pooled and fixed effects regression to a panel for the period 2000-2009. The empirical results exhibit that credit risk and operating expenses have a significant and positive impact on NIM. The results also show that during the high inflation the NIM is wider, while market concentration and growth have negative impact on NIM.

Ćuraka, Poposkib and Pepura (2012) seek to examine the bank-level, industry-level and macroeconomic factors of profitability of Macedonian banking sector by using a dynamic panel consisting of 16 banks and a period between 2005 and 2010. Their findings reveal that operating expense is the most important determinant of profitability. It is also seen from the findings that the liquidity risk and solvency risk affect the profitability. The findings also suggest that concentration, banking system reform and economic growth have significant impact on bank profitability.

By taking data from 1929 banks in 40 advanced and emerging economies for a period from 1999 to 2008 Mirzaei, Moore, and Liu (2013) empirically examine the effects of market structure on profitability by incorporating the relative-market-power (RMP) hypotheses and traditional structure-conduct- performance (SCP) hypotheses. They find that a high level of market share directs to a high level of bank profitability by supporting the RMP hypothesis in advanced economies. On the opposite of these findings, for emerging economies none of the hypotheses is supported.

On the basis of Malmquist index approach Lee and Kim (2013) develop an appraisal for performance of banks in Korea as there are some limitations for measuring performance by using ROA and ROE. They find no significant evidence for the existence of economies of scale. They conclude that foreign banks have the probability to raise their performance. It is also observed from their findings that foreign buyouts funds and the management control of government have the negative impact on bank profitability.

Berger and Bouwman (2013) investigate the impact of capital on bank's performance. They find that capital helps banks with small size to raise their market share and probability of survival at all times including normal times, market crises and banking crises. They also find that capital increases the performance of banks with large and medium size in the period of banking crises.

Apergis (2014) empirically examine the impact of non-traditional bank activities on profitability by using a data from 1725 U.S. financial institutions for the period of 2000-2013.The empirical results show that non-traditional bank activities have a positive effect on the profitability. From the literature it is seen that most of the studies are done on developed countries. A very few studies are done on developing countries. In single country study, Sufian and Habibullah (2009) work on Bangladesh. But the main limitation of the study is that they ignore the endogeneity problem between profitability, risk and capital. Moreover they use data from 1997 to 2004 before the adaptation of BASEL II. As per our knowledge goes this is the first empirical study on Bangladesh as a single country study by using latest data and by using GMM system of estimator developed by Arellano and Bover (1995) to count both the potential endogeneity and serial correlation problem.

\section{Data, Variables and Econometric Model}

This section is divided into three parts. Part 1 deals with the data and sample. Part 2 reports the both dependent and independent variables. Part 3 presents the econometric model.

\subsection{Data}

At the $31^{\text {st }}$ December 2014 there are 57 commercial banks working in Bangladesh consisting 4 state-owned banks, 9 foreign banks, 39 private-owned commercial banks, and 5 state-owned development financial institutions not for running commercial purposes rather they are used for special purposes. Government, foreign investors, private investors, and government are the owner of state-owned, foreign banks, private-owned and state-owned development financial institutions respectively. Among these banks, 30 banks are listed in stock 
exchange and 27 are not listed in stock exchange.

The main objective of the study is to investigate the main factors of bank profitability in Bangladesh. Therefore profitability is the dependent variable and three alternative measures of profitability are used in this study. They are ROA, NIM, and Tobin's q. On the basis of previous literature, two types of determinants are used in this study: bank-level determinants and macroeconomic determinants. The study is mainly based on secondary data. Data for dependent variable is collected from the balance sheet and income statement (published annual reports) as well as individual website of banks. Data for bank-level factors are obtained from the balance sheet and income statement as well as website of selected banks. The initial sample consists of 57 banks from Bangladesh. 18 commercial banks are excluded from the sample as they are very new and there are no data for those banks. We also exclude 5 specialized banks from the sample because they do not run any commercial activities. 9 foreign banks are also excluded from the sample due to unavailability of data. Finally the sample consists selected 25 Bangladeshi commercial banks for a period of 2006-2013. The data for all the banks in sample are not available for all the years; therefore an unbalanced panel data is used in the study for not losing degrees of freedom. Thus samples composed of 25 banks in Bangladesh. The data for macroeconomics determinants are collected from the website of Bangladesh Bank (http://www.bangladesh-bank.org) as well as the World Development Indicator 2014 (http://data.worldbank.org). The selected variables that affect the bank profitability are based on previous literature and theory.

The main objective of the study as stated earlier is to identify the important determinants of bank profitability in Bangladesh. Therefore two types of variables are used: dependent and independent variables. Profitability is the dependent variable and capital/regulatory capital, risk, bank size, ownership structure, non interest income, cost to income, off-balance sheet activities, total loan to total deposits, GDP growth rate and inflation are used as independent variable as well as potential determinants of profitability.

\subsection{Bank Profitability and Its Determinants}

This section describes both bank profitability as dependent variable and its determinants as independent variables.

\subsubsection{Dependent Variables}

This study uses three different measures of bank profitability. They are (i) return on assets (ROA), (ii) net interest margin over total assets (NIM), and (iii) return of equity (ROE). ROA is the main measure of profitability of banks. ROA is the net profits expressed as a percentage of total assets. It depicts the profits earned per taka of assets and gives signal that how effectively the bank's assets are being managed by authority to generate revenues. ROA is used to evaluate the competence and operational performance of banks as it examines the profits generated from the assets invested by the bank (Jahan, 2012; Golin, 2001).

First alternative measure of profitability is the NIM which is defined as the net interest margin over total assets is the difference between interest earned and interest expended by a bank divided by its total assets. According to Dietrich and Wanzenried (2011), the NIM shows the profit earned on interest activities. Second alternative measure of profitability is ROE which is defined as the ratio between net profits and equity capital expressed as a percentage. This is the return to the shareholders on their equity capital, but in the literature this is not the best measure of profitability (Dietrich \& Wanzenried, 2011). This is because, banks with a high level of equity shows a higher ROA but a lower ROE. Therefore, in this study ROA is used as the main dependent variable, although we also show the results of NIM and ROE.

\subsubsection{Independent Variables: Determinants of Profitability}

The independent variables i.e. the potential determinants of bank profitability are reported in this section. There are basically two types of independent variables used in this study. They are bank specific and macroeconomic factors.

Capital: The capital (CAP) of banks includes mainly funds from issuing shares and retained earnings. Bank capital acts as a safety net in the case of adverse development (Athanasoglou et al., 2008). Two concepts of capital are mainly used in literature, for example (i) actual capital and (ii) regulatory capital. Actual capital is also known as physical capital which is composed of equity and long-term debt and is represented in the balance sheet of banks. It is usually measured as the ratio of equity to total assets and also known as capital ratio. Regulatory capital is the capital based on risk which is maintained in accordance with the rules determined by supervisor in a country. This capital is measured as the ratio of capital to risk-weighted assets and also known as risk-based capital adequacy ratio (CAR). National regulators track a bank's CAR to ensure that it can absorb a reasonable amount of loss and complies with statutory capital requirements. Based on the previous literature, it is 
found a mix relationship between capital and bank profitability. The relationship between capital and bank profitability is said to be unpredictable (Sharma \& Gounder, 2012). Some studies show that there is a positive relationship between capital and bank profitability (Berger 1995; Demirgüc- Kunt \& Huizinga, 1999; Hassan \& Bashir, 2005; Athanasoglou et al., 2008; Dietrich \& Wanzenrid, 2009; Davydenko, 2010; Olweny \& Shipho, 2011; Ani, Ugwunta, Ezeudu, \& Ugwuanyi, 2012; Rao \& Lakew, 2012). On the other hand, some studies show that there is a negative relationship between capital and bank profitability (Saona, 2011; Ali, Akhtar, \& Ahmed, 2011; Qin \& Pastory, 2012). Therefore it can be said that the impact of capital on profitability cannot be anticipated theoretically.

Risk: Based on the literature, risk can be analyzed through various ways, namely credit risk, market risk, liquidity risk, overall risk etc. In this study, we consider only credit risk. In the literature, credit risk is measured by the ratio of non-performing loan to total loans (NPLTL), and a higher ratio indicates that there is more risk for losses from loan defaults (Zhang, Jiang, \& Wang, 2013). Changes in credit risk may reflect changes in the health of a bank's loan portfolio (Cooper, Jackson, \& Patterson, 2003). Previous studies regarding credit risk show a mix picture about the relationship with profitability. Studies of Davydenko (2010), Ali et al. (2011), Sufian (2011), and Ramlall (2009) depict that provisions for loans are significant and have a strong negative effect on profitability. Another measure of credit risk is loan loss provision to total loans which indicates the ability of banks to absorb losses from non-performing loans (Zhang et al., 2013). Syafri (2012) finds that loan loss provision to total loan has a positive effect on profitability. A low level of credit quality is reported by a high level of ratio, and hence a low level of profitability.

Bank Size: Bank size (SIZE) is considered as an important determinant of bank profitability. SIZE has an impact on various activities of banks including investing opportunities, portfolio diversification, reputation and access to equity capital (Zhang, Jun, \& Qiong-fang, 2008). As the large banks have easy access to equity capital market, thus a large bank will have lower capital ratio than smaller banks (Aggarwal \& Jacques, 2001). In addition, as large banks can carry out a large number of different activities, so they can diversify their portfolio, and, hence credit risk will be decreased (Roy, 2008). The SIZE is measured as the natural logarithms of total assets. Kosmidou, Tanna and Pasiouras (2002), Alper and Anbar (2011) and Khrawish (2011) find positive relationship between ROA and bank size. On the other hand, Syafri (2012) find that bank size has negative effect on profitability.

Ownership Structure (Dummy Variable): Bank ownership (OWND) structure will be included as a dummy variable in the equation to see the impact of bank ownership on profitability. This dummy variable equals 1 if the bank is a private commercial bank and 0 for otherwise. Ownership structure affects the principal-agent relationships that influence profitability of banks (Barth, Caprio, \& Levine, 1999; Boubakri, Cosset, \& Saffar, 2013; Agusman, Cullen, Gasbarro, Monroe, \& Zumwalt, 2013; Iannotta, Nocera, \& Sironi, 2013). Based on the previous literature it is found that, the effect of differences in bank ownership on profitability is indeterminate, and there is even disagreement among the empirical studies. The studies of Bourke (1989), Molyneux and Thornton (1992) and Dietrich and Wanzenried (2011) find no significant relationship between the ownership status and the performance of a bank. On the other hand, Micco et al. (2007) and Iannotta et al. (2007) find strong empirical evidence that ownership does affect bank profitability.

Non-interest income to total assets: Non-interest income to total assets (NIITA) is considered as an important determinant of bank profitability and is calculated as total non-interest income divided by total assets. Non-interest income consists of commission, service charges, and fees, guarantee fees, net profit from sale of investment securities, and foreign exchange profit. The study of Mujeri and Younus (2009) shows that the ratio of non-interest income to total assets of a bank and its spread has a negative effect on profitability.

Cost-to-income ratio: Cost to income ratio (COSTINC) which is referred as cost efficiency is also used as an important determinant of banks' profitability (Pasiouras and Kosmidou, 2007). This ratio is used to see the effect of efficiency of management regarding expenses on banks profitability. Higher ratio indicates the less efficiency of management. This is the ratio that indicates the running costs of the banks and the major element of it is the salaries and benefits of the staffs. This is expected to have a negative relationship between cost to income ratio and profitability. Previous studies show a negative relationship between cost to income ratio and profitability (Syafri, 2012; Kosmidou, 2008).

Off-Balance Sheet items to total assets: Off-balance sheet activity also referred as non-traditional activity also affects the profitability of banks (Apergis, 2014). Therefore, the ratio of off-balance sheet items to total assets (OFBSTA) is considered as a determinant of profitability. As a result, this ratio is included in the equation of profitability to capture off-balance sheet activities. Off-balance sheet activities help banks to raise their sources 
of income without changing capital structure (Deelchand \& Padgett, 2009).

Total loan to total assets: Banking activities are also influenced by liquidity risk (LIQUIDITY) which refers to the risk of not having enough cash reserves to meet the demands of withdrawals from depositors. The loan structure, especially loans to individuals and firms, is risky than the others forms of credit for example government securities. Hence there is a greater return from loans than a return from other earning assets. Liquidity risk is measured by the ratio of total loans divided by total assets. Sufian (2009) finds a positive association between profitability and liquidity risk. A positive association between liquidity risk and profitability is expected.

GDP Growth Rate: As a macroeconomic indicator gross domestic products (GDP) is a measure of the total economic activities of a country. It is assumed to have a positive impact of growth in GDP on profitability of banks (Pasiouras \& Kosmidou, 2007; Demirgüc-Kunt \& Huizinga, 1999; Bikker \& Hu, 2002; Athanasoglou et al., 2008). In this study annual growth in GDP (GGDP) is used as a potential determinant of profitability.

Inflation: Banking performance is highly influenced by inflation (INFL). The findings from the previous studies regarding the relationship between inflation and profitability are varied. The studies of Hussain and Hassan (2005), Khrawish (2011) and Syafri (2012) show that there is a significant negative impact of inflation on profitability. On the other hand, there is a positive impact of inflation on risk. Studies by Wallich (1980), Vong and Chan (2007) and Tan and Floros (2012) show that high inflation rates lead to higher bank profitability. The following Table 1 shows the list of variables with their acronyms and definition.

Table 1. List of variables and their definition

\begin{tabular}{|c|c|c|c|c|}
\hline Variables & & Acronym & Definition & Expected sign \\
\hline \multicolumn{5}{|l|}{ Dependent Variable } \\
\hline \multirow{3}{*}{ Profitability } & \multirow{3}{*}{ PROFIT } & ROA & Net profit after tax divided by total assets & Not applicable \\
\hline & & NIM & $\begin{array}{l}\text { Difference between interest earned and interest expended by } \\
\text { a bank divided by its total assets }\end{array}$ & Not applicable \\
\hline & & ROE & Net profit after tax divided by shareholders' equity & Not applicable \\
\hline \multicolumn{5}{|l|}{ Bank-level Determinants } \\
\hline \multirow{2}{*}{ Capital } & \multirow{2}{*}{ CAP } & CAP & Shareholders' equity divided by total assets & \multirow{2}{*}{$+/-$} \\
\hline & & CAR & Capital to risk weighted assets & \\
\hline \multirow{2}{*}{ Risk } & \multirow{2}{*}{ RISK } & NPLTL & Ratio of non-performing loans to total loans & \multirow[b]{2}{*}{$+/-$} \\
\hline & & LLPTL & Ratio of loan-loss provisions to total loans & \\
\hline Bank size & & SIZE & Natural logarithm of total assets & $+/-$ \\
\hline Ownership structure & & OWND & $\begin{array}{l}\text { Ownership dummy is equal } 1 \text { if the bank is private-owned } \\
\text { bank and } 0 \text { for otherwise. }\end{array}$ & $+/-$ \\
\hline Non-interest income & & NIITA & Non-interest income to total assets & + \\
\hline Cost efficiency & & COSTINC & Ratio of cost to income & - \\
\hline Nontraditional activities & & OFBSTA & Total of off-balance sheet activities divided by total assets & + \\
\hline Liquidity & & LIQUIDITY & Ratio of total loans to total assets & + \\
\hline \multicolumn{5}{|c|}{ Macroeconomic Determinants } \\
\hline $\begin{array}{l}\text { Growth in gross } \\
\text { domestic product }\end{array}$ & & GGDP & Growth in annual gross domestic products & $+/-$ \\
\hline Inflation & & INFL & Annual inflation rate & $+/-$ \\
\hline
\end{tabular}

\subsection{Econometric Model}

On the basis of selected variables and literature review the following econometric model is developed to see the impact of potential determinants on profitability of banks in Bangladesh.

$$
\begin{gathered}
\text { PROFIT }_{i t}=\alpha+\beta_{1} \text { CAP }_{i t}+\beta_{2} \text { RISK }_{i t}+\beta_{3} \text { SIZE }_{i t}+\beta_{4} \text { OWND }_{i t}+\beta_{5} \text { NIITA }_{i t}+\beta_{6} \text { COSTINC }_{i t}+\beta_{7} \text { OFBSTA }_{i t}+\beta_{8} \text { LIQUIDITY }_{i t}+ \\
\beta_{9} G G D P_{i t}+\beta_{I 0} I N F L_{i t}+\varepsilon i
\end{gathered}
$$

Where the cross-sectional dimension across banks is presented by subscript $i$, and the time dimension is presented by t. $\varepsilon_{\text {it }}$ represents error term. As stated earlier the main objective of the study is to identify the main determinants of profitability of banks in Bangladesh. PROFIT is used as a proxy for profitability. Three different measures (ROA, NIM, and ROE) of profitability are used in this study. CAP is used as a proxy for capital. Owners' equity to total assets and capital to risk weighted assets are used as proxy for capital. Banks in 
Bangladesh have to maintain a capital of $10 \%$ on risk weighted assets or TK 4,000 million which one is higher. Two different measures of risk (NPLTL, and LLPTL) are used to see the impact of risk on profitability. To see the potential effect from SIZE the natural logarithmic value of total assets is used as a proxy for bank size.

In Bangladesh most of the cases licenses for banks are given to political persons. Hence due to political and other influence ownership structure (OWND) plays an important role in the profitability of banks. To capture this effect OWND is included in the equation as a dummy variable to proxy for ownership structure and OWND equals 1 if the bank is a private commercial bank and 0 for otherwise. One of the main sources of income for banks is commissions, brokerages and fees. To capture the impact of non-interest income NII is used as a proxy for it. To show the impact of cost efficiency CTI is used as a proxy for cost to income ratio. Now a days non-traditional activities of banks are also take major parts of profitability. To show the impact of non-traditional activities OFBSTA is included in the equation and is proxied by the ratio of off-balance sheet activities to total assets. Banking activities are also influenced by risk of not having enough cash reserves to meet the demands of withdrawals from depositors which is proxied by LIQUIDITY. For capturing effects form macro-economic factors on profitability GGDP and INFL are used as proxy for annual economic growth and annual inflation rate.

\section{Empirical Findings}

\subsection{Descriptive Statistics}

Descriptive statistics of all variables used in the study are reported in the following Table 2. It is seen from the table that the average value of three profitability measures are $1.33 \%, 2.38 \%$ and $16.69 \%$ for ROA, NIM, and ROE respectively. The maximum values for ROA, NIM, and ROE are $3.54 \%, 4.86 \%$ and $53.75 \%$ respectively where as the minimum values are $-10.28 \%,-1.29 \%$, and $-59.94 \%$ respectively. The standard deviation for ROA and ROE are 1.32 and 1.02 respectively which implies that ROA, and NIM vary very slightly from bank to bank. On the contrary to this ROE varies highly from bank to bank. The average CAR is $11.15 \%$ which is higher than the minimum requirement of $10 \%$ in Bangladesh where as the maximum value is $16.84 \%$ with a negative minimum value $(-6.01 \%)$. The average of equity to total assets is $7.85 \%$, whereas the maximum value is $15.42 \%$ and minimum value is $-8.06 \%$. Average credit risk represented by NPLTL is $5.23 \%$ and represented by LLPTL is $2.75 \%$. The NPLTL ranges from a maximum $44.59 \%$ to a minimum $0.031 \%$ whereas the LLPTL ranges from a maximum $27.50 \%$ to a minimum $0 \%$. The average NIITA is $3.2 \%$ with a standard deviation of 0.013 . The NIITA ranges from a maximum $8.4 \%$ to a minimum $0.5 \%$. The mean value of cost efficiency (COSTINC) is $55.69 \%$ with a standard deviation of $16.45 \%$, whereas the maximum and minimum values of COSTINC are $94.96 \%$ and $28.59 \%$ respectively. It is also seen from the table that the average OFBSTA and LIQUIDITY are $29.50 \%$ and $67.05 \%$ respectively. The maximum value of OFBSTA is $73.14 \%$ with a minimum value of $2.98 \%$. The LIQUIDITY ranges from a maximum $82.51 \%$ to a minimum $40.30 \%$. In case of macroeconomic variables, the average values of GGDP and INFL are $6.23 \%$ and $8.21 \%$ respectively. The average, standard deviation, maximum and minimum value of other variables are also reported in Table 2.

Table 2. Descriptive statistics

\begin{tabular}{ccccccccc}
\hline Variables & Mean & Maximum & Minimum & Std. Dev. & Skewness & Kurtosis & Jarque-Bera & Observations \\
\hline ROA & 1.33 & 3.54 & -10.28 & 1.32 & -4.70 & 37.92 & 9755.75 & 179 \\
NIM & 2.38 & 4.86 & -1.29 & 1.02 & -0.41 & 3.59 & 7.68 & 179 \\
ROE & 16.69 & 53.75 & -59.94 & 25.37 & -8.05 & 83.81 & 50648.18 & 179 \\
CAR & 11.15 & 16.84 & -6.01 & 2.62 & -3.28 & 22.48 & 3153.87 & 179 \\
EQUITYTA & 7.85 & 15.42 & -8.06 & 2.62 & -0.89 & 10.03 & 392.89 & 179 \\
NPLTL & 5.23 & 44.59 & 0.031 & 6.46 & 3.22 & 14.71 & 1334.36 & 179 \\
LLPTL & 2.75 & 27.50 & 0 & 4.56 & 3.49 & 15.47 & 1525.38 & 179 \\
SIZE & 11.48 & 13.65 & 9.91 & 0.78 & 0.40 & 3.01 & 4.81 & 179 \\
OWND & 0.88 & 1 & 0 & 0.32 & -2.37 & 6.65 & 268.48 & 179 \\
NIITA & 0.032 & 0.084 & 0.005 & 0.013 & 1.18 & 6.38 & 127.45 & 179 \\
COSTINC & 55.69 & 94.96 & 28.59 & 16.45 & 0.28 & 1.97 & 10.14 & 179 \\
OFBSTA & 29.50 & 73.14 & 2.98 & 11.23 & 0.26 & 3.44 & 3.62 & 179 \\
LIQUIDITY & 67.05 & 82.51 & 40.30 & 8.09 & -0.78 & 3.65 & 21.54 & 179 \\
GGDP & 6.23 & 6.7 & 5.74 & 0.30 & 0.09 & 2.08 & 6.51 & 179 \\
INFL & 8.21 & 10.62 & 6.66 & 1.37 & 0.65 & 1.90 & 21.67 & 179 \\
\hline
\end{tabular}




\subsection{Correlation Analysis}

Table 3 reports the degree of correlation between the variables used in the study. Pearson's correlation coefficients are used to show the degree of relationship. It is observed from the matrix that the correlation between the explanatory variables does not support the severe existence of the problem of multicollinearity. According to Kennedy (2008), multicollinearity creates problems when the correlation exceeds 0.80 which is not found here. The matrix shows that CAR, EQUITYTA, OWND, NIITA, OFBSTA AND LIQUIDITY are positively and significantly associated with ROA. On the opposite of this, NPLTL, LLPTL, SIZE, COSTINC and INFL are negatively and significantly associated with ROA. NIM is positively and significantly associated with CAR, EQUITYTA, OWND, NIITA, LIQUIDITY. On the contrary to this, NIM is negatively and significantly related with NPLTL, LLPTL, SIZE, COSTINC. Finally, ROE is positively and significantly associated with CAR, EQUITYTA, OWND, LIQUIDITY. On the other hand, ROE is negatively and significantly affected by NPLTL, LLPTL, SIZE, COSTINC, INFL. It can be concluded from the correlation matrix that capital, ownership structure, non-interest income, liquidity risk affect the bank profitability positively and significantly. On the other hand, credit risk, bank size, cost efficiency affect the bank profitability negatively and significantly.

Table 3. Correlation matrix for the dependent and independent variables

\begin{tabular}{|c|c|c|c|c|c|c|c|c|c|c|c|c|c|c|c|}
\hline & ROA & NIM & ROE & CAR & EQUITYTA & NPLTL & LLPTL & SIZE & OWND & NIITA & COSTINC & OFBSTA & LIQUIDITY & GGDP & INFL \\
\hline ROA & 1 & $.394^{\cdots * *}$ & $.616^{\cdots *}$ & $.646^{* *}$ & $.633^{\cdots *}$ & $-.553^{\cdots}$ & $-.526^{* *}$ & $-.325^{\cdots *}$ & $.450^{\cdots * *}$ & $.250^{\ldots *}$ & $-.250^{\ldots *}$ & $.179^{* *}$ & $.322^{\cdots *}$ & -.109 & $-.193^{* *}$ \\
\hline NIM & & 1 & $.262 \cdots$ & $.260^{* *}$ & $.426^{*}$ & $-.546^{\cdots \cdots}$ & $-.497^{\cdots * *}$ & $-.284^{\cdots *}$ & $.444^{\cdots *}$ & $.129^{\circ}$ & $-342^{\ldots * *}$ & .071 & $.419^{\prime *}$ & .039 & .030 \\
\hline ROE & & & 1 & $.519^{\cdots *}$ & $.214^{\cdots *}$ & $-.410^{\ldots * *}$ & $-.384^{\ldots * *}$ & $-.285^{\cdots *}$ & $.272^{\cdots *}$ & .088 & $-.136^{*}$ & .096 & $.246^{*}$ & -.051 & $-.282^{\cdots}$ \\
\hline CAR & & & & 1 & $.553^{\cdots *}$ & $-.405^{\cdots \cdots}$ & $-.362^{\cdots * *}$ & $-.285^{\cdots *}$ & $.416^{* *}$ & .026 & -.084 & -.064 & $.126^{\circ}$ & -.084 & -.057 \\
\hline EQUITYTA & & & & & 1 & $-.426^{* * *}$ & $-.401^{\cdots *}$ & -.027 & $.388^{* * *}$ & $.345^{\cdots *}$ & $-.226 *$ & $.234^{\cdots *}$ & $.204^{\cdots *}$ & -.071 & .008 \\
\hline NPLTL & & & & & & 1 & $.952^{\cdots *}$ & $.594^{\cdots \cdots}$ & $-.811^{\cdots *}$ & -.085 & $.204^{\cdots \cdots}$ & $-.212^{\ldots *}$ & $-.663^{\cdots *}$ & -.037 & .074 \\
\hline LLPTL & & & & & & & 1 & $.610^{\circ * *}$ & $-.804 \cdots$ & -.072 & $.165^{\circ}$ & $-.244^{\ldots * \cdots}$ & $-.648^{\cdots \cdots *}$ & -.052 & .047 \\
\hline SIZE & & & & & & & & 1 & $-.655^{\cdots * *}$ & -.019 & .062 & -.089 & $-.605^{\cdots * *}$ & $-.162^{*}$ & $.259^{\cdots \cdots}$ \\
\hline OWND & & & & & & & & & 1 & .037 & $-.215^{\cdots *}$ & $.126^{\circ}$ & $.644^{\cdots *}$ & .037 & -.027 \\
\hline NIITA & & & & & & & & & & 1 & $-.449^{* \cdots *}$ & $.460^{\cdots *}$ & -.048 & $-.124^{*}$ & $-.158^{* *}$ \\
\hline COSTINC & & & & & & & & & & & 1 & $-.321^{\cdots \cdots}$ & .006 & -.005 & .047 \\
\hline OFBSTA & & & & & & & & & & & & 1 & $.220^{\circ *}$ & .124 & -.087 \\
\hline LIQUIDITY & & & & & & & & & & & & & 1 & .091 & -.095 \\
\hline GGDP & & & & & & & & & & & & & & 1 & $.235^{\cdots}$ \\
\hline INFL & & & & & & & & & & & & & & & 1 \\
\hline
\end{tabular}

Note. The table shows the results of Pearson's Correlation Coefficients. $* * *, *$, and * indicates significance at $1 \%, 5 \%$, and $10 \%$ respectively.

\subsection{Regression Analysis}

The empirical findings by equation (1) as stated earlier to determine the determinants of bank profitability are presented in Table 4,5 and 6. For potential endogeneity and serial correlation problem GMM system of estimator technique is used. For Model 1 to 12, Hausman test shows that the capital and credit risk are endogenous variable in equation 1 irrespective of different measures of capital and credit risk. P-values from Serial correlation test for Model 1 to 4 and Model 9-12 where ROA and ROE are dependent variables respectively are not significant which suggest that the error terms are not auto correlated. The p-values from Serial correlation test for Model 5-8 are significant; hence the null hypothesis of no serial correlation is rejected. The results suggest that the error terms are correlated. Sargan test for all models show that the instruments are valid.

Table 4 shows the results of GMM estimator where ROA is the dependent variable. It is seen from the table that capital adequacy has a positive but insignificant impact on ROA where the relation is positive and significant when equity to total asset is used as a proxy for capital. The later relationship suggests that capital serves as a signal for creditworthiness of banks in Bangladesh. It is observed from the table that credit is negatively and significantly associated with ROA which implies that banks can increase their profitability by lowering the credit risk. This is because amount of loan defaults are increasing day by day in Bangladesh. Ownership dummy is negatively related with ROA which suggests that private commercial banks have a tendency to have lower profitability than comparable state-owned banks. SIZE confirms the existence of economies of scale as the 
relationship between bank SIZE and ROA is positive and significant. The Table 5 also shows that NIITA has a positive and significant impact on ROA which reveals that banks with a high level non-interest income tends to have a high level of ROA. As expected cost efficiency has a negative and significant impact on ROA which suggest that higher the cost efficiency (Low level of cost to income ratio) higher the profitability. Beyond our expectation we get a negative relationship between non-traditional activities proxied by OFBSTA and ROA which implies that banks involving more off-balance sheet activities have lower level of ROA. It is also found that LIQUIDITY has a significant and positive impact on ROA which reveal that banks with a high level of liquidity earn more. So significant relationship is found between banks' profitability and GGDP. On the other hand, INFL has a significant and negative impact on ROA which implies that during high inflation banks earn less. It can be concluded from adjusted $\mathrm{R}^{2}$ that $45.93 \%, 40.21 \%, 53.88 \%$, and $42.93 \%$ variation in $\mathrm{ROA}$ is explained by Model 1, 2, 3, and 4 respectively.

Table 4. Impact of selected determinants on profitability (PROFIT= ROA)

\begin{tabular}{|c|c|c|c|c|}
\hline Variables & Model 1 & Model 2 & Model 3 & Model 4 \\
\hline CAR & $0.05(0.65)$ & $0.09(0.95)$ & & \\
\hline EQUITYTA & & & $0.25 * * *(3.04)$ & $0.24 * * *(3.12)$ \\
\hline NPLTL & $-0.14 * * *(-4.14)$ & & $-0.03(-0.78)$ & \\
\hline LLPTL & & $-0.08 *(-1.72)$ & & $-0.05(-0.81)$ \\
\hline OWND & $-0.92 *(-1.67)$ & $-0.42(-0.84)$ & $-0.69(-1.24)$ & $-0.64(-1.06)$ \\
\hline SIZE & $0.12(1.58)$ & $0.15 *(1.87)$ & $0.19 *(1.75)$ & $0.19 *(1.77)$ \\
\hline NIITA & $19.74 * * *(4.21)$ & $20.31 * * *(4.29)$ & $0.13(0.02)$ & $0.53(0.06)$ \\
\hline COSTINC & $-0.01(-1.58)$ & $-0.01 * *(-1.92)$ & $-0.01 * * *(-2.42)$ & $-0.01 * *(-2.51)$ \\
\hline OFBSTA & $-0.01(-1.29)$ & $-0.01 *(-1.67)$ & $-0.01 *(-1.72)$ & $-0.01(-1.21)$ \\
\hline LIQUIDITY & $0.04 * * *(3.28)$ & $0.05 * * *(4.46)$ & $0.06(0.72)$ & $0.06 * * *(5.35)$ \\
\hline GGDP & $0.03(0.23)$ & $-0.02(-0.11)$ & $0.06(0.36)$ & $0.06(0.40)$ \\
\hline INFL & $-0.13 * * *(-2.66)$ & $-0.19 * * *(-2.78)$ & $-0.17 * * *(-2.86)$ & $-0.17 * * *(-2.79)$ \\
\hline Adj. $R^{2}$ & $45.93 \%$ & $40.21 \%$ & $53.88 \%$ & $42.93 \%$ \\
\hline Hausman Test, F(p-value) & $21.79(.000)$ & $19.65(.000)$ & $22.95(.000)$ & $20.64(.000)$ \\
\hline Sargan test (p-value) & 0.474 & 0.521 & 0.204 & 0.305 \\
\hline Serial correlation test ( $p$-value) & 0.879 & 0.758 & 0.775 & 0.601 \\
\hline Observations & 179 & 179 & 179 & 179 \\
\hline Number of banks & 25 & 25 & 25 & 25 \\
\hline
\end{tabular}

Note. The table shows the empirical results from GMM panel estimator. Dependent variable is ROA for all four models. ***,** and * indicate significance at the $1 \%, 5 \%$ and $10 \%$ respectively. t-statistics are shown in parentheses . For Hausman test p-values are in parentheses.

Table 5 shows the results of GMM estimator where NIM is the dependent variable. It is seen from the results that CAR and EQUITYTA are positively and significantly related with NIM which implies that banks with a high level of capital earn more net interest margin. Credit risk measured by NPLTL is positively associated with NIM, but the relationship is not statistically significant. Credit risk measured by LLPTL is positively and significantly associated with NIM which suggests that banks taking more credit risk earn more. Ownership structure is not an important factor of NIM. Non-interest income is positively and significantly associated with NIM which implies that banks with a low level of non-interest income perform better. It is also seen from the table that cost efficiency is negatively and significantly affects the profitability which is in accordance our expectation. Non-traditional activities are negatively and significantly associated with NIM which reveals that banks with highly involvement in off-balance sheet activities earn lower profitability in terms of NIM. 
Table 5. Impact of selected determinants on profitability (PROFIT= NIM)

\begin{tabular}{|c|c|c|c|c|}
\hline Variables & Model 5 & Model 6 & Model 7 & Model 8 \\
\hline CAR & $0.79 *(1.91)$ & $0.06(0.94)$ & & \\
\hline EQUITYTA & & & $0.12(1.41)$ & $0.22 * *(2.21)$ \\
\hline NPLTL & $0.03(0.74)$ & & $0.02(0.29)$ & \\
\hline LLPTL & & $0.09 *(1.72)$ & & $0.20 * *(2.27)$ \\
\hline OWND & $-0.36(-0.55)$ & $0.93(1.28)$ & $-0.05(-0.09)$ & $1.24 *(1.76)$ \\
\hline SIZE & $0.08(0.92)$ & $-0.07(-0.87)$ & $-0.09(-0.70)$ & $-0.32 * *(-2.08)$ \\
\hline NIITA & $-10.49 * *(-1.98)$ & $-14.06 * *(-2.49)$ & $-17.07 * *(-2.23)$ & $-30.44 * * *(-3.11)$ \\
\hline COSTINC & $-0.02 * * *(-6.38)$ & $-0.03 * * *(-6.32)$ & $-0.02 * * *(-6.75)$ & $-0.03 * * *(-5.60)$ \\
\hline OFBSTA & $-0.02 * *(-2.33)$ & $-0.02 * *(-2.05)$ & $-0.03 * * *(-4.29)$ & $-0.02 * * *(-3.29)$ \\
\hline LIQUIDITY & $0.04 * * *(3.53)$ & $0.44 * * *(4.25)$ & $0.05 * * *(4.78)$ & $0.06^{* * *}(4.70)$ \\
\hline NIM(-1) & $0.58 * * *(6.95)$ & $0.57 * * *(7.39)$ & $0.44 * * *(5.66)$ & $0.49 * * *(5.78)$ \\
\hline GGDP & $-0.19(-1.11)$ & $0.16(-0.89)$ & $0.09(0.64)$ & $0.08(0.41)$ \\
\hline INFL & $0.06 *(1.75)$ & $0.04(0.81)$ & $0.01(0.22)$ & $0.01(0.22)$ \\
\hline Adj. $R^{2}$ & $39.28 \%$ & $26.18 \%$ & $41.08 \%$ & $21.23 \%$ \\
\hline Hausman Test, F(p-value) & $21.76(.000)$ & $18.19(.000)$ & $22.38(.000)$ & $20.59(.000)$ \\
\hline Sargan test (p-value) & 0.324 & 0.451 & 0.209 & 0.438 \\
\hline Serial correlation test ( $\mathrm{p}$-value) & 0.000 & 0.000 & 0.000 & 0.000 \\
\hline Observations & 179 & 179 & 179 & 179 \\
\hline Number of banks & 25 & 25 & 25 & 25 \\
\hline
\end{tabular}

Note. The table shows the empirical results from GMM panel estimator. Dependent variable is NIM for all four models. $* * *, * *$ and $*$ indicate significance at the $1 \%, 5 \%$ and $10 \%$ respectively. t-statistics are shown in parentheses . For Hausman test p-values are in parentheses.

It is also found from the result that LIQUIDITY has a positive and significant impact on NIM which suggests that banks with a high level of liquidity earn more NIM. NIM is also positively and significantly related with lagged value of NIM proxied by NIM(-1) which reveals that banks with a high level of NIM in previous year earn more NIM in current year and vice-versa. No significant association between macroeconomic factors and NIM is found in this study. It can be said from the adjusted $\mathrm{R}^{2}$ that $39.28 \%, 26.18 \%, 41.08 \%$, and $21.23 \%$ variation in NIM is explained by Mdel 5, 6, 7, and 8 respectively.

Table 6 shows the results of GMM estimator where ROE is the dependent variable. The table shows that capital adequacy is positively and significantly related with ROE, but the relationship is not significant when equity to total assets is proxied for capital. The positive relation implies that banks holding higher capital irrespective of nature earn more profitability in terms of ROE. Credit risk is not found as a significant determinant of ROE but it is seen that banks taking more credit risk earn less. Ownership structure is significantly and negatively related with ROE which suggests that private commercial banks have a tendency to have lower ROE than comparable state-owned banks.

It is also seen from the table that NIITA is positively and significantly related with ROE which implies that banks with a high level of non-interest income show high ROE. According to our expectation we get a negative and significant relationship between cost efficiency and ROE that is banks with lower cost to income ratio earn more ROE.

In respect of macroeconomic variables Table 6 also reports that INFL is negatively and significantly related with ROE, but the relationship between GGDP and ROE is not statistically significant. Negative relationship between INFL and ROE suggests that during the high inflation the banks earn less. It is also seen from the table that $40.22 \%, 49.93 \%, 50.12 \%$, and $41.23 \%$ variation is RE is explained by the Model 9,10,11, and 12 respectively.

Table 6. Impact of selected determinants on profitability (PROFIT= ROE)

\begin{tabular}{lllll}
\hline Variables & Model 9 & Model 10 & Model 11 & Model 12 \\
\hline CAR & $1.78^{* *}(1.81)$ & $1.85^{* *}(1.93)$ & & $0.40(0.43)$ \\
EQUITYTA & & & $-0.23(-0.48)$ & $0.52(0.60)$ \\
NPLTL & $-0.1401(-0.31)$ & & & $-1.05(-1.23)$ \\
LLPTL & & $-0.95(-1.20)$ & $-20.23 * *(-3.21)$ & $-25.10^{* * *}(-3.41)$ \\
OWND & $-19.35^{* * *}(-2.71)$ & $-26.22 * * *(-3.17)$ & $0.12(0.10)$ & $0.69(0.58)$ \\
SIZE & $-1.43(-1.36)$ & $-1.15(-1.38)$ & $137.79 *(1.67)$ & $164.56^{* *}(2.05)$ \\
NIITA & $120.86^{* *}(2.06)$ & $130.92^{* *}(2.17)$ & $-0.13 * *(-2.41)$ & $-0.12 * *(-2.07)$ \\
COSTINC & $-0.10^{* *}(-1.73)$ & $-0.089(-1.38)$ & $-0.04(-0.77)$ & $-0.11(-1.43)$ \\
OFBSTA & $0.03(0.46)$ & $-0.03(-0.39)$ & & \\
\hline
\end{tabular}




\begin{tabular}{|c|c|c|c|c|}
\hline LIQUIDITY & $0.64 * * *(4.74)$ & $0.63 * * *(5.08)$ & $0.78 * * *(6.19)$ & $0.76^{* * *}(6.61)$ \\
\hline GGDP & $-0.16(-0.08)$ & $0.99(0.46)$ & $0.63(0.29)$ & $1.09(0.49)$ \\
\hline INFL & $-0.99(-1.59)$ & $-1.39 * *(-1.96)$ & $-1.48 * *(-2.25)$ & $-1.68 * *(-2.37)$ \\
\hline Adj. $R^{2}$ & $40.22 \%$ & $49.93 \%$ & $50.12 \%$ & $41.23 \%$ \\
\hline $\begin{array}{l}\text { Hausman } \quad \text { Test, } \\
\mathrm{F} \text { (p-value) }\end{array}$ & $22.70(.000)$ & $21.53(.000)$ & $22.67(.000)$ & $20.79(.000)$ \\
\hline Sargan test (p-value) & 0.506 & 0.423 & 0.201 & 0.378 \\
\hline $\begin{array}{l}\text { Serial correlation test } \\
\text { (p-value) }\end{array}$ & 0.765 & 0.879 & 0.775 & 0.543 \\
\hline Observations & 179 & 179 & 179 & 179 \\
\hline Number of banks & 25 & 25 & 25 & 25 \\
\hline
\end{tabular}

Note. The table shows the empirical results from GMM panel estimator. Dependent variable is ROE for all four models. ***,** and * indicate significance at the $1 \%, 5 \%$ and $10 \%$ respectively. t-statistics are shown in parentheses. For Hausman test p-values are in parentheses.

\section{Conclusion and Suggestions}

As a developing country Bangladesh has taken a number of financial reforms which affect the overall banking system as well as banking profitability. Most of the studies on the determinants including the reforms of bank profitability are done on developed and some developing countries like China, Pakistan, and India etc. Till to date there are very few study on the determinants of bank profitability in Bangladesh but there are some limitations in those studies. For example, Sufian and Habibullah (2009) do not consider the problem of endogeneity between profitability, capital and risk. Moreover, they work on old data from 1997 to 2004. This study attempts to investigate the bank specific and macroeconomic determinants of bank profitability by using an unbalanced panel data consisting 25 banks for a period 2006 to 2013.

The empirical findings show that bank specific factors, particularly capital strength (both regulatory and equity capital) and loan intensity (liquidity) have positive and significant impact on bank profitability. On the opposite to this, results also suggest that cost efficiency and off-balance sheet activities have negative and significant impact on profitability. It is also evident from the results that the impact of credit risk, non-interest income, ownership structure, bank size, growth in GDP and inflation is not uniform across the different measures of bank profitability used in this study. Non-interest income has a significant and positive impact on ROA and ROE, but the relationship is negative and significant for NIM. Credit risk is found to have a positive and significant impact on NIM only. Bank size is found as an important determinant of profitability when ROA is used as a proxy for profitability. Results also show that ownership structure has a significant influence on ROE. In respect of macroeconomic factors GGDP is found as an important factor for NIM and opposite to this inflation is found as an important determinant of ROA and ROE.

\section{References}

Aggarwal, R., \& Jacques, K. T. (2001). The impact of FDICIA and prompt corrective action on bank capital and risk: Estimates using a simultaneous equations model. Journal of Banking \& Finance, 25, 1139-1160. http://dx.doi.org/10.1016/S0378-4266(00)00125-4

Agusman, A., Cullen, G. S., Gasbarro, D., Monroe, G. S., \& Zumwalt, J. K. (2013). Government intervention, bank ownership and risk-taking during the Indonesian financial crisis. Pacific-Basin Financial Journal, 30, 114-131. http://dx.doi.org/10.1016/j.pacfin.2014.07.003

Albertazzi, U., \& Gambacorta, L. (2008). Bank profitability and the business cycle. Journal of Financial Stability, 5, 393-409. http://dx.doi.org/10.1016/j.jfs.2008.10.002

Ali, K., Akhtar, M. F., \& Ahmed, H. Z. (2011). Bank Specific and Macroeconomic Indicators of Profitability Empirical Evidence from the Commercial banks of Pakistan. International Journal of Business and Social Science, 2(6), 235-242.

Alper, D., \& Anbar, A. (2011). Bank Specific and Macroeconomic Determinants of Commercial Bank Profitability: Empirical Evidence from Turkey. Business and Economics Research Journal, 2(2), 139-152.

Ani, W. U., Ugwunta, D. O., Ezeudu, I. J., \& Ugwuanyi, G. O. (2012). An Assessment of the Determinants of bank Profitability in Nigeria: Bank Characteristics Panel Evidence. Journal of Accounting and Taxation, 4(3), 38-43. http://dx.doi.org/10.5897/jat11.034

Apergis, N. (2014). The long-term role of non-traditional banking in profitability and risk profiles: Evidence 
from a panel of U.S. banking institutions. Journal of International Money and Finance, 45, 61-73. http://dx.doi.org/10.1016/j.jimonfin.2014.03.003

Arellano, M., \& Bover, O. (1995). Another look at the instrumental-variable estimation of error-components model. Journal of Econometrics, 68(1), 29-52. http://dx.doi.org/10.1016/0304-4076(94)01642-d

Athanasoglou, P. P., Brissimis, S. N., \& Delis, M. D. (2008). Bank-specific, industry-specific and macroeconomic determinants of bank profitability. International Financial Markets, Institutions and Money, 18, 121-136. http://dx.doi.org/10.1016/j.intfin.2006.07.001

Barth, J. R., Caprio, G., \& Levine, R. (1999). Banking Systems Around the Globe: Do Regulation and Ownership Affect Performance and Stability? World Bank Policy Research Working Paper No. 2325.

Beck, T., \& Rahman, M. H. (2006). Creating a More Efficient Financial System: Challenges for Bangladesh. World Bank Policy Research Working Paper 3938.

Berger, A. N. (1995). The Relationship between Capital and Earnings in Banking. Journal of Money, Credit and Banking, 27, 432-456. http://dx.doi.org/10.2307/2077877

Berger, A. N., \& Bouwman, C. H. S. (2013). How does capital affect bank performance during financial crises? Journal of Financial Economics, 109, 146-176.

Bikker, J., \& Hu, H. (2002). Cyclical patterns in profits, provisioning and lending of banks and procyclicality of the New Basel Capital Requirements. BNL Quarterly Review, 22(1), 143-175.

Bolt, W., Haan, L. D., Hoeberichts, M., Oordt, M. R. C. V., \& Swank, J. (2012). Bank profitability during recessions. Journal of Banking \& Finance, 36, 2552-2564. http://dx.doi.org/10.1016/j.jbankfin.2012.05.011

Boubakri, N., Cosset, J., \& Saffar, W. (2013). The role of state and foreign owners in corporate risk-taking: Evidence from privatization. Journal of Financial Economics, 108, 641-658. http://dx.doi.org/10.1016/j.jfineco.2012.12.007

Bourke, P. (1989). Concentration and other determinants of bank profitability in Europe, North America, and Australia. Journal of Banking and Finance, 13, 65-79. http://dx.doi.org/10.1016/0378-4266(89)90020-4

Chirwa, E. W. (2003). Determinants of commercial banks' profitability in Malawi: A cointegration approach. Applied Financial Economics, 13(8), 565-571. http://dx.doi.org/10.1080/0960310022000020933

Claeys, S., \& Vennet, R. V. (2008). Determinants of bank interest margins in Central and Eastern Europe: A comparison with the West. Economic Systems, 32, 197-216. http://dx.doi.org/10.1016/j.ecosys.2007.04.001

Cooper, M., Jackson, W., \& Patterson, G. (2003). Evidence of predictability in the cross section of bank stock $\begin{array}{llll}\text { returns. Journal of Banking and } & \text { 817-850. }\end{array}$ http://dx.doi.org/10.1016/S0378-4266(01)00263-1

Ćuraka, M., Poposkib, K., \& Pepura, S. (2012). Profitability Determinants of the Macedonian Banking Sector in Changing Environment. Procedia-Social and Behavioral Sciences, 44, 406-416. http://dx.doi.org/10.1016/j.sbspro.2012.05.045

Davydenko, A. (2010). Determinants of Bank Profitability in Ukraine. Undergraduate Economic Review, 7(1/2).

Deelchand, T., \& Padgett, C. (2009). The Relationship between Risk, Capital and Efficiency: Evidence from Japanese Cooperative Banks. ICMA Centre Discussion Papers in Finance DP 2009-2012. doi.org/10.2139/ssrn.1525423

Demirgüc-Kunt, A., \& Huizinga, H. (1999). Determinants of Commercial Bank Interest Margins and Profitability: Some International Evidence. The World Bank Economic Review, 13(2), 379-408.

Dietrich, A., \& Wanzenried, G. (2011). Determinants of bank profitability before and during the crisis: Evidence from Switzerland. Journal of International Financial Markets, Institutions \& Money, 21, 307-327. http://dx.doi.org/10.1016/j.intfin.2010.11.002

Doliente, J. S. (2005). Determinants of bank net interest margins in Southeast Asia. Applied Financial Economics Letters, 1(1), 53-57. http://dx.doi.org/10.1080/1744654042000303629

Fama, E. F. (1980). Banking in the theory of finance. Journal of Monetary Economics, 6, 39-57.

García-Herrero, A., Gavilá, S., \& Santabárbara, D. (2009). What explains the low profitability of Chinese banks? Journal of Banking \& Finance, 33, 2080-2092. http://dx.doi.org/10.1016/j.jbankfin.2009.05.005

Golin, J. (2001). The Bank Credit Analysis Handbook: A Guide for Analysts, Bankers and Investors. John Wiley 
\& Sons (Asia) Pre Ltd.

Hassan, M. K., \& Bashir, A. H. (2005). Determinants of Islamic Banking Profitability. In Munawar Iqbal and Rodney Wilson (Eds.), Islamic Perspectives on Wealth Creation, Edinburgh: Edinburgh University Press.

Heffernan, S. A., \& Fu, X. (2010). Determinants of financial performance in Chinese banking. Applied Financial Economics, 20(20), 1585-1600. http://dx.doi.org/10.1080/09603107.2010.505553

Ho, T. S. Y., \& Saunders, A. (1981). The determinants of bank interest margins: Theory and empirical evidence. The Journal of Financial and Quantitative Analysis, 16(4), 581-600. http://dx.doi.org/10.2307/2330377

Hussain, M. E., \& Hassan, M. K. (2005). Basel Capital Requirements and Credit Risk Taking in Developing Countries. Department of Economics and Finance Working Papers, 1991-2006, Paper 34.

Iannotta, G., Nocera, G., \& Sironi, A. (2013). The impact of government ownership on bank risk. Journal of Financial Intermediation, 22, 152-176. http://dx.doi.org/10.1016/j.jfi.2012.11.002

Jahan, N. (2012). Determinants of Bank's Profitability: Evidence from Bangladesh. Indian Journal of Finance, $6(2), 32-38$.

Kennedy, P. (2008). A guide to econometrics. Malden, Massachusetts: Blackwell Publishing.

Khediri, K. B., \& Ben-Khedhiri, H. (2011). Determinants of bank net interest margin in Tunisia: A panel data model. Applied Economics Letters, 18(13), 1267-1271. http://dx.doi.org/10.1080/13504851.2010.534052

Khrawish, H. A. (2011). Determinants of Commercial Banks Performance: Evidence from Jordan. International Research Journal of Finance and Economics, 81, 148-159.

Kosmidou, K. (2008). The determinants of banks' profits in Greece during the period of EU financial integration. Managerial Finance, 34(3), 146-159. http://dx.doi.org/10.1109/03074350810848036

Kosmidou, K., Pasiouras, F., \& Tsaklanganos, A. (2007). Domestic and multinational determinants of foreign bank profits: The case of Greek banks operating abroad. Journal of Multinational Financial Management, 17, 1-15. http://dx.doi.org/10.1016/j.mulfin.2006.02.002

Kosmidou, K., Tanna, S., \& Pasiouras, F. (2002). Determinants of profitability of domestic UK commercial banks: Panel evidence from the period 1995-2002. Money Macro and Finance (MMF) Research Group Conference, 45.

Kutan, A. M., Ozsoz, E., \& Rengifo, E. W. (2012). Cross-sectional determinants of bank performance under deposit dollarization in emerging markets. Emerging Markets Review, 13, 478-492. http://dx.doi.org/10.1016/j.ememar.2012.07.003

Lee, J. Y., \& Kim, D. (2013). Bank performance and its determinants in Korea. Japan and the World Economy, 27, 83-94. http://dx.doi.org/10.1016/j.japwor.2013.05.001

Micco, A., Panizza, U., \& Yañez, M. (2007). Bank ownership and performance. Does politics matter? Journal of Banking \& Finance, 31(1), 219-241. http://dx.doi.org/10.1016/j.jbankfin.2006.02.007

Mirzaei, A., Moore, T., \& Liu, G. (2013). Does market structure matter on banks' profitability and stability? Emerging vs. advanced economies. Journal of Banking \& Finance, 37, 2920-2937. http://dx.doi.org/10.1016/j.jbankfin.2013.04.031

Molyneux, P., \& Thornton, J. (1992). Determinants of European Bank Profitability: A Note. Journal of Banking and Finance, 16(6), 1173-1178. http://dx.doi.org/10.1016/0378-4266(92)90065-8

Mujeri, M. K., \& Younus, S. (2009). An Analysis of Interest Rate Spread in the Banking Sector in Bangladesh. The Bangladesh Development Studies, 32(4), 1-33.

Naceur, S. B., \& Kandil, M. (2009). The impact of capital requirements on banks' cost of intermediation and performance: The case of Egypt. Journal of Economics and Business, 61, 70-89. http://dx.doi.org/10.1016/j.jeconbus.2007.12.001

Naceur, S. B., \& Omran, M. (2011). The effects of bank regulations, competition, and financial reforms on banks' performance. Emerging Markets Review, 12, 1-20. http://dx.doi.org/10.1016/j.ememar.2010.08.002

Olweny, T., \& Shipho, T. M. (2011). Effects of Banking Sectoral Factors on the Profitability of Commercial Banks in Kenya. Economics and Finance Review, 1(5), 1-30.

Park, K. H., \& Weber, W. L. (2006). Profitability of Korean banks: Test of market structure versus efficient structure. Journal of Economics and $22-239$. 
http://dx.doi.org/10.1016/j.jeconbus.2005.09.003

Pasiouras, F., \& Kosmidou, K. (2007). Factors influencing the profitability of domestic and foreign commercial banks in the European Union. Research in International Business and Finance, 21, 222-237. http://dx.doi.org/10.1016/j.ribaf.2006.03.007

Qin, X., \& Pastory, D. (2012). Commercial Banks Profitability Position: The Case of Tanzania. International Journal of Business and Management, 7(13), 136-144. doi.org/10.5539/ijbm.v7n13p136

Ramlall, I. (2009). Bank-Specific, Industry-Specific and Macroeconomic Determinants of Profitability in Taiwanese Banking System: Under Panel Data Estimation. International Research Journal of Finance and Economics, 34, 160-167.

Rao, K. R. M., \& Lakew, T. B. (2012). Determinants of Profitability of Commercial Banks in a Developing Country: Evidence from Ethiopia. International Journal of Accounting and Financial Management Research, 2(3), 1-20.

Roy, P. V. (2008). Capital Requirements and Bank Behavior in the Early 1990s: Cross-Country Evidence. International Journal of Central Banking, 4(3), 29-60.

Saona, P. H. (2011). Determinants of the Profitability of the US Banking Industry. International Journal of Business and Social Science, 2(22), 255-269.

Sharma, P., \& Gounder, N. (2012). Profitability Determinants of Deposit Institutions in Small, Underdeveloped Financial Systems: The Case of Fiji. Griffith Business School Discussion Papers Finance, No. 2012-06.

Sufian, F. (2009). Determinants of Bank Profitability in a Developing Economy: Empirical Evidence from the China Banking Sector. Journal of Asia-Pacific Business, 10(4), 281-307. http://dx.doi.org/10.1080/10599230903340205

Sufian, F. (2011). Profitability of the Korean Banking Sector: Panel evidence on bank-specific and Macroeconomics Determinants. Journal of Economics and Management, 7(1), 43-72.

Sufian, F. (2012). Determinants of bank profitability in developing economies: empirical evidence from the South Asian banking sectors. Contemporary South Asia, 20(3), 375-399. http://dx.doi.org/10.1080/09584935.2012.696089

Sufian, F., \& Habibullah, M. S. (2009). Determinants of bank profitability in a developing economy: Empirical evidence from Bangladesh. Journal of Business Economics and Management, 10(3), 207-217. http://dx.doi.org/10.3846/1611-1699.2009.10.207-217

Syafri. (2012). Factors Affecting Bank Profitability in Indonesia. The International Conference on Business and Management. Phuket, Thailand.

Tan, Y., \& Floros, C. (2013). Risk, capital and efficiency in Chinese banking. Journal of International Financial Markets, Institutions \& Money, 26, 378-393. http://dx.doi.org/10.1016/j.intfin.2013.07.009

Tarusa , D. K., Yonas, B. C., \& Mutwolc, M. (2012). Determinants of Net Interest Margins of Commercial Banks in Kenya: A Panel Study. Procedia Economics and Finance, 2, 199-208. http://dx.doi.org/10.1016/S2212-5671(12)00080-9

Uddin, S. M. S., \& Suzuki, Y. (2011). Financial Reform, Ownership and Performance in Banking Industry: The Case of Bangladesh. International Journal of Business and Management, 6(7), http://dx.doi.org/10.5539/ijbm.v6n7p28

Vong, P. I., \& Chan, H. S. (2007). Determinants of Bank Profitability in Macao. Macau Monetary Research Bulletin, 12(6), 93-113.

Wallich, H. C. (1980). Bank profits and inflation. Federal Reserve Bank of Richmond Economic Review.

Westman, H. (2011). The impact of management and board ownership on profitability in banks with different strategies. Journal of Banking \& Finance, 35, 3300-3318. http://dx.doi.org/10.1016/j.jbankfin.2011.05.013

Zhang, J., Jiang, C., Qu, B., \& Wang, P. (2013). Market concentration, risk-taking, and bank performance: Evidence from emerging economies. International Review of Financial Analysis, 30, 149-157. http://dx.doi.org/10.1016/j.irfa.2013.07.016

Zhang, Z., Jun, W., \& Qiong-fang, L. (2008). Impacts of Capital Adequacy Regulation on Risk-taking Behaviors of Banking. Systems Engineering-Theory \& Practice, 28(8), 183-189. http://dx.doi.org/10.1016/S1874-8651(09)60035-1 


\section{Copyrights}

Copyright for this article is retained by the author(s), with first publication rights granted to the journal.

This is an open-access article distributed under the terms and conditions of the Creative Commons Attribution license (http://creativecommons.org/licenses/by/3.0/). 